\title{
Reactivation of Latent Varicella Zoster Virus
}

\author{
M. Cholis
}

\begin{abstract}
Abstrak
Reaktivasi dari keadaan laten virus varisela-zoster (VZV) menyebabkan terjadinya herpes zoster. Dalam keadaan laten, dapat dideteksi tiga gen VZV yaitu ORF-29, ORF-62, dan ORF-63. Sistem imun berperan penting dalam pengendalian reaktivasi VZV. Varisela banyak dijumpai pada anak-anak, sedangkan herpes zoster pada orang dewasa. Pada penderita yang sehat, herpes zoster dan varisela dapat menimbulkan rasa sakit dan keadaan yang tidak menyenangkan, bahkan dapat mengancam jika tidak diobati. Hasil beberapa penelitian menunjukkan bahwa herpes zoster memberi respon yang baik terhadap pengobatan yang tepat.
\end{abstract}

\begin{abstract}
Reactivation of the latent VZV results in herpes zoster. Three VZV genes, ORF-29, ORF-62, and ORF-63 have been detected during latent infection. The importance of the immune system in controlling reactivation of VZV is clearly understood. Both varicella and herpes zoster are common. The former in childhood, the latter increasing in incidence with age. In healthy patients, they can be extremely painful and cause unpleasant conditions; both are life threatening if not treated. Many studies show that herpes zoster do respond to
the correct treatment.
\end{abstract}

Keywords: Latency, Immune respons, Pathogenesis, Herpes zoster, Treatment

The varicella-zoster virus (VZV) is a member of the herpes virus family and responsible for both varicella and herpes zoster. The important cytological characteristics of VZV are the affinity for tissues of ectodermal origin and the ability to cause latent infection.

Latency is required for the persistence of VZV in the host and this virus has evolved elaborate mechanism to control the latent state. Reactivation of the latent virus, usually many decades later, leads to herpes zoster. The implication of reactivation depends on the virus involved and the immune status of the host. ${ }^{1}$

This paper discuss some aspects of reactivation of VZV including latency, mechanism, clinical implication, and methods of limiting the consequences of reactivation.

\section{VIRAL FACTORS INVOLVED IN LATENCY}

Latent viral infections are defined as persistent infections in which the viral genome is present, but gene

Departement of Dermato-Venereology School of Medicine, Brawijaya University / Regional General Hospital

Dr. Saiful Anwar, Malang, Indonesia expression is limited and infectious virus is not produced. In general, the herpes viruses are lytic pathogens, destroying most of the cells that they infect. However, during the course of a primary infection, some viruses express latent functions which restrict the expression of viral genes and enable the cell harbouring the virus to survive.

The VZV genome consists of a linear molecule of double stranded DNA 125.000 base pairs in length. It is similar in organization to the genomes of herpes simplex virus (HSV-1 and HSV-2). The complete sequence of the VZV genome has been determined. It contains open reading frame (ORF) corresponding to approximately 70 genes, many of which have DNA sequence and functional homology to HSV genes, and some of which can even complement their HSV homologs. VZV replication is thought to be analogous to HSV, and VZV genes are grouped in similar classes.

During primary infection, VZV infects the upper respiratory tract leading to primary viraemia which result in varicella. VZV then establishes latency in sensory ganglia, most commonly the trigeminal and thoracic ganglia. However, precisely which cells contain this DNA is a controversial issue. Some data incriminate neurones and satellite cells. ${ }^{1,2}$ 
In contrast to HSV, where only latency-associated transcripts (LATs) are transcribed, several regions of the VZV genome are expressed during latent infection, although no viral-encoded antigens have been detected. During latent infection, three VZV genes, ORF-29, ORF-62 and ORF-63 have been detected by in situ hybridization. ORF-29 encodes the VZV major DNA-binding protein. The exact role of this protein is still unknown. But the DNA- binding property indicates that it has regulatory activities on gene expression. ORF-62 encodes the major immediate early gene transactivator, and ORF-63 down-regulates transactivation by ORF- 62 and may therefore repress the production of infectious virus. ${ }^{2}$

\section{THE HOST FACTORS INVOLVED IN LATEN- CY}

Wood (1993) states that intact immune responses to VZV especially cell mediated immunity (CMI), are required in maintaining VZV in the latent state. The immune system has an important role in limiting the effect of primary VZV infection and in constraining the infection to a latent state. Although host immunity does not prevent reactivation, it is likely that the host response plays an important role in rapidly controlling this events. Therefore immunocompromised patients are much more likely to have frequent and severe reactivation of latent VZV infection. The loss of cellular immune function allows the latent VZV to reactivate and causes herpes zoster. ${ }^{3}$

The primary aims of the host immune response are to promote host survival, rescue infected cells and establish lifelong immunity to reinfection. In achieving this aims the virus may be contained or eliminated. ${ }^{3,4}$

Antibody-dependent cell-mediated cytotoxicity (ADCC) is an important component of the host response to infection. Virally-encoded proteins are processed into peptides and presented by major histocompatibility complex (MHC) class I molecules to the T-cell receptors of $\mathrm{CD} 8^{+}$cytotoxic T-lymphocytes, causes subsequent lysis of the infected cell (Figure 1). The classic antiviral response, which cause the lysis of infected cells by cytotoxic T- lymphocytes, is essential when the host needs to destroy an infected cell. ${ }^{2,5}$

In general, herpes viruses and the human host are very well adapted to one another and it may not be in the interest of the host to eradicate latency. In theory, down regulation of the MHC class I molecules which are vital for immune recognition, would be a valuable means of evading the immune response. Numerous cytokines are secreted by cellular immune cells, e.g. $\gamma$-interferron, which can affect the transcriptional environment of neighbouring cells. In this way, lytic infection may be prevented and cellular function maintained in a delicate balance with the latent state. ${ }^{2,4}$

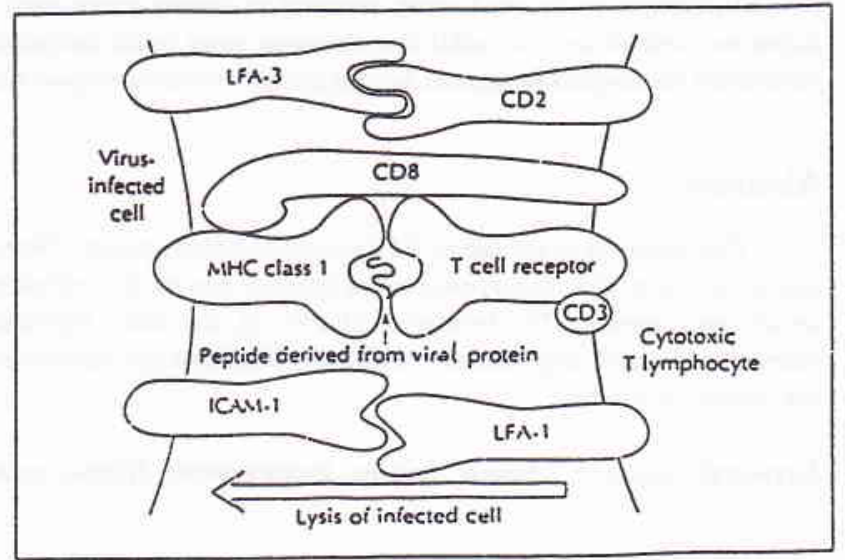

Figure 1. Interaction between the immune system and a viral infected cell. $C D 8^{+}$cylotoxic T-lymphocyte (CTL) recognition of a virus-infected cell: a short peptide fragment derived from a viral protein is presented to the $T$ cell receptor in association with a particular MHC class I molecule; the CTL-target cell interaction is stabilized by $C D 8$ binding to the MHC class I molecule and by the specific binding of various adhesion molecules (only the LFA-1-ICAM-1 and LFA3-CD2 interactions are shown). ${ }^{2}$

\section{REACTIVATION OF LATENT VZV INFEC- TION}

During the course of varicella, VZV passes from lesions in the skin and mucosal surfaces into the contiguous endings of sensory nerves and is transported centripetally up the sensory fibers to the sensory ganglia. In the ganglia a latent infection is established and the virus then persists silently and harmlessly. The mechanisms involved in the activation of latent VZV are unclear, but a number of conditions have been associated with the occurence and localization of herpes zoster. These include immunosuppression in HIV infection, Hodgkin's disease and other malignancies; administration of immunosuppressive drugs and corticosteroids; irradiation of the spinal column, tumor involving the spinal cord, local trauma, heavy metal poisoning or therapy, and frontal sinusitis. ${ }^{2,6}$ 
The level of antibody is considered to be the critical determinant of the host's capacity to contain VZV reversions. There is evidence for subclinical reactivations of VZV in immunocompromised patients and in the elderly, and it has been suggested that a similar phenomenon may periodically occur in immunocompetent individuals to boost specific immunity and maintain latency. ${ }^{7,8}$

In latent VZV infection, the minute dose of infectious virus that results is immediately neutralized by circulating antibody or destroyed by cellular immune responses before it can infect other cells and multiply enough to cause perceptible damage. However, in the activation of latent VZV infection, virus multiplies and spreads within the ganglion, causing neuronal necrosis and intense inflammation; this process is usually accompanied by severe neuralgia. Infectious VZV then spreads antidromically down the sensory nerve, causing intense neuritis, and is released from the sensory nerve endings to the surrounding skin where it produces the characteristic cluster of zoster vesicles.

The incidence of herpes zoster is estimated to be between 1.3 and 4.8 cases per 1,000 population per year, and increases with age. Herpes zoster is relatively uncommon in those less than 40 years old. ${ }^{9}$ Lumintang (1993) from Indonesia reported that the prevalence of herpes zoster was less than $1 \% .^{10}$

\section{IMPLICATION OF REACTIVATION}

In herpes zoster, at the time of acute illness, pain is a result of inflammation. However, as a result of damage to nerves in which the reactivated virus is multiplying, chronic pain, can persist for months or even years after the rash has healed.

With increasing number of elderly people in developed countries, the number of herpes zoster cases will increase and hence the number of patients suffering from the most frequent complication of herpes zoster: chronic zoster-associated pain.

Patients with herpes zoster are infectious and may transmit varicella to succeptible individuals. The route of transmission of VZV is predo-minantly respiratory, which gives it the ability to spread very effectively in epidemics and the majority of the succeptible population is infected during childhood.

Primary infection or reactivation of VZV during pregnancy carries the risk of congenital varicella syndrome, which although rare can have a serious outcome for the infected infant. ${ }^{2,3}$

\section{METHODS OF LIMITING THE CONSEQUEN- CES OF REACTIVATION}

\section{Vaccination}

While CMI appears to be important for the prevention of reactivation, the persistence of humoral immune responses especially has been correlated with protection from reinfection, which may occur in individuals who develop low titers of antibody after immunization. It is therefore important that both arms of the immune response are maintained after vaccination. Trials with the Oka strain of VZV showed that persistence of cellular and humoral immune responses occured in the majority of those vaccinated, and were consistent with those achieved after natural infection with VZV at 6 years after immunization.

The Oka vaccine has been used successfully in children in Japan to prevent varicella and has recently been approved for use in the USA. However, the virus used in the vaccine is just as neurotropic as the wild-type and it is possible that widespread vaccination of children could result in a shorter-lasting immunity, and consequently, there will be more cases of herpes zoster following a vaccination compared to natural infection. This has not been the case to date, but research for the development of a non-neurotropic vaccine should continue. $^{2,6}$

It is not yet known what impact the widespread vaccination of adults will have on the incidence of herpes zoster. Studies in leukemic children, who are at much higher risk of developing herpes zoster (incidence rate of 10-20\%) compared to healthy children (incidence rate of 0.05-0.074\%), showed that the incidence of herpes zoster was actually lower in vaccine recipients than among those who acquired varicella naturally. ${ }^{2,9}$

Varicella immunization in elderly boosts VZV specific CMI and may therefore decrease the incidence and severity of herpes zoster. Currently, no data are available to confirm whether immunization attenuates or prevents herpes zoster, but a large study is planned in the USA, involving 27.000 seropositive adults over 60 years of age to assess the protective effects of vaccination.

\section{Antiviral therapy}

Moorthy (1993) stated that the aims of therapy in herpes zoster included the reduction of the acute symptoms and the risk of complications. ${ }^{11}$ 
To impact on chronic zoster-associated pain, antiviral therapy should subsequent nerve damage. A 7-day course of aciclovir ( $800 \mathrm{mg}$ five times daily) has been shown to confer significant benefit to the patient for the management of zoster-associated pain. Aciclovir also accelerates the events of cutaneous healing and shortens the duration of virus shedding. ${ }^{11,12}$

The daily dose regimen of aciclovir for herpes zoster mentioned above is recommended also by the Indonesian Herpes Study Group (1995). ${ }^{13}$ The combined data from all the multicenter trials indicate that oral aciclovir results in significant benefit for patients with herpes zoster. ${ }^{13,14,15}$

The advent of new antiviral agents will expand the range of antiviral therapies available to the practitioner. A 7-day course of valaciclovir (1000 $\mathrm{mg}$ three times daily) resolves zoster-associated pain about onethird faster than aciclovir. Other published data showed that famciclovir $(250 \mathrm{mg}$ three times daily (UK) or $500 \mathrm{mg}$ three times daily (USA)) produced similar results to aciclovir in reducing the duration of zoster-associated pain. In the immunocompromised individual with herpes zoster, intravenous aciclovir therapy may be required if there is a risk of visceral dissemination. ${ }^{2,15}$

\section{CONCLUSION}

1. Latency of VZV is not a resting, but a dynamic state. It involves a complex interrelationship between the virus, host cell and the immune system.

2. Reactivation of the latent VZV can be triggered by risk factors and result in herpes zoster.

3. In elderly, but otherwise immunocompetent patients, the most common complication of herpes zoster is chronic zoster-associated pain or post-herpetic neuralgia.

4. The use of Oka-live vaccine for the prevention of varicella in healthy children is controversial, though it was proven beneficial in reducing the risk of varicella in immuno-compromised individuals.

5. Antiviral therapy should be offered routinely to all patients over the age of 50 years presenting with herpes zoster within 72 hours of rash onset. Valaciclovir appears to be the most effective choice of antivirai therapy.

\section{REFERENCES}

1. Otmann MN, Alani R. Varicella and Herpes Zoster. In: Fitzpatrick TB, Eizen AZ, Wolf K, Freedberg IM, Austen KT, eds. Dermatolology In General Medicine, vol $2.4^{\text {th }} \mathrm{Ed}$. New York; Mc Graw Hill, 1993:2543-67.

2. Whitely RJ, Sandstrom E, editors. The Clinical Implications of Herpes virus Latency. Proceeding of the $3^{\text {rd }}$ Annual Meeting of The International Herpes Management Forum on The Clinical Implications of Herpes virus Latency; 1995 Nov 17-20; Istambul. Istambul: International Herpes Management Forum, 1995.

3. Wood M, editor. How can the burden of zoster-associated pain be reduced? Proceeding of The International Herpes Management Forum Strategies Workshop on How can the burden of zoster-associated pain be reduced?; 1993 May 15; Washington DC. Washington DC: Intemational Herpes Management Forum, 1993.

4. Paul WE. Infectious Diseases And The Immune System. Scientific American 1993; September:57-63.

5. Joklik WK, Willet HP, Amos DB, Wilfert CM. Immune responses in infection. In: Joklik WK, Willet HP, Amos DB, Wilfert CM, editors. Zinsser Microbiology. $20^{\text {th }}$ Ed. Connecticut; Prentice Hall, 1992:352-7.

6. Arvin AM. Cell Mediated Immunity to Varicella-zoster Virus. J Infect Dis 1992;166 Suppl 1:35-41.

7. Masaoka T, Hirauka A, Teshima H, Tominaga N. Varicellazoster Virus Infection In Immunocompromised Patients. J Med Virol 1993;1 Suppl 1:82-4.

8. Teroda K, Kawano S, Yoshihito K. Varicella-zoster virus reactivation is related to the low response of $\mathrm{V} \mathrm{Z} \mathrm{V}$ specific immunity after chickenpox infancy. J Infect Dis 1994; 169:650-2.

9. Hardy I, Cherson AA, Steinberg SP. The Incidence of zoster after immunization with the live-attenuated varicella vaccine, A Study in children with leukemia. N Engl J Med 1991;325(22): 1545-50.

10. Lumintang H. Epidemiologi Virus Herpes Hominis di RSUD Dr. Soetomo Surabaya. Airlangga Period DermatolVenereol 1993;6(1):1-8.

11. Moorthy TT. Herpes Virus Infection, The Enigma and Chalengers. Airlangga Period Dermatol-Venereol 1993; 6(1):13-21.

12. Balfour HH. Current Management of Varicella Zoster Virus Infection. J Med Virol 1993;1 Suppl 1:74-80.

13. Daili SF, Budiardja SA, Zuber F, Makes WIB, eds. Infeksi Herpes, Pedoman Pengobatan Asiklovir untuk Dokter. Jakarta; Kelompok Studi Herpes Indonesia, 1995.

14. Fiddian AP, Mills J. Therapeutic Options For Zoster. J International Herpes Management Forum 1995; 2(3):77-80.

15. Balfour HH. Clinical Aspects of Chicken Pox and Herpes Zoster. J International Medical Research 1994;22 (1 Suppl):3-10. 